Kövér Ágnes

Eötvös Lorán Tudományegyetem

\title{
„A genderideológia berúgta az ajtót Magyarországon is", avagy ideológiai továbbképzés szociális szakembereknek
}

A Szociálpolitikai Tükör III. évfolyam 1-2. számát túlnyomórészt a „genderideológiával" való végleges leszámolásnak szentelték, ${ }^{1}$ melynek aktualitást feltehetően a 2021. évi LXXIX. törvény „a pedofil bünelkövetökkel szembeni szigorúbb fellépésröl, valamint a gyermekek védelme érdekében egyes törvények módositásáróp' elfogadása adott. Ennek a törvénynek a szellemében felmelegítésre került a „genderideológia” szlogen, ismételt csapást kellett mérni a feminizmusra és mindezt a veszélyes bűnelkövetôkkel való összefüggésben kellett megtenni, egy kalap alá boronálva a gendert, a feminizmust, a szexuális kisebbségi jogokat a pedofil bűncselekményekkel és a pedofil búnelkövetők iránti szigorúbb fellépéssel. S mindezt természetesen a „gyermekek érdekeinek védelmében”. A főszerkesztői (Lakner Z. Lehel ${ }^{2}$ ) bevezető, egy oldalas un. vezércikke a „Hús” címet viseli, amely már önmagában megbélyegzô kíván lenni, Simone de Beauvoir A Második Nem című nagyhatású írására utalva. Lakner Z. Lehel azt írja: „Boldogtalan emlékü Simone de Beauvoir a hatvanas években még csake nem is sejtette mit is indit el kijelentése az anyamébben növekevô magzatról. Az csak egy darab buis.-- irta,..."

\section{„Így írtok Ti” vagy „Így ferdítetek Ti”?}

„Hús”-nak fordítani az eredeti francia „la chair” vagy az angol fordításban „flesh” szót rossz indulatú torzítás. Bár tény, hogy a szó a „hús” megjelölésére

${ }^{1}$ A szám 17 írása közül 7 szól valamilyen formában a társadalmi nemmel kapcsolatos nézetek sajátos értelmezéséről és megbélyegzéséről. A legélesebb és legelvakultabb támadást a Lakner Zoltán Lehel által írt főszerkesztôi vezércikk tartalmazza, illetve az a két másik írás, amelyre ez a tanulmány hivatkozik, Lakner Zoltán Lehel és Antalóczy Péter tollából.

2 Nekem így könnyebb emlegetnem Lakner Zoltán Lehelt, mert így elkerülhető az, hogy Lakner Zoltánra, az ELTE Szociálpolitikai Tanszékén oktató kiváló kollégánkra bármilyen módon is emlékeztessen. 
is szolgál, azonban mind az eredeti francia, mind az angol fordítás szövegkörnyezetéből egyértelműen kiviláglik, hogy a „test” jelentést hordozza. Ezt a magyar fordítók (Görög Lívia, Somló Vera és a fordítás lektora, Tordai Zádor) tökéletesen értették és a „la chair”, illetve a „flesh” fordítására a „test” szót választották. A „flesh” és „la chair” szavak az emberi testnek a fizikai részét, a bőrt és az izmokat hangsúlyozzák és nem a testet, mint egészet. Mégsem a „hús” jelentés az autentikus. A kontextusából kiragadott és jelentéséből kiforgatott kifejezés arra szolgál, hogy elmondja a főszerkesztő: de Beauvoir "a feminizmustól lázas homlokkal nézett tudatlanul a genderarcú jövöbe” - azaz a mi jelenünkbe. Pedig érdemes lett volna elferdítés helyett tovább olvasni a szöveget, ami valójában így szól:

Mert a gyereket nem teremti [az anya], csak benne terem; teste csak testet szülhet, nem új szabadságot, mert azt csak a létező maga konstituálhatja. A szabadság alkotásai értékként tételezik tárgyukat, és szükségszerűséggel ruházzák fel: a magzat véletlen burjánzás az anyaméhben, léte nem igazolt; természeti tény, s mint ilyen éppoly esetleges, mint a halál. ... Bizonyos értelemben minden anya megéli az inkarnáció csodáját. Minden újszülött egy-egy emberré lett isten; ha nem jönne a világra, nem valósíthatná meg önmagát tudatként és szabadságként, az anya tehát közremúködik a csodatételben; de az nem az ő múve, a méhében formálódó lény végső, lényegi igazsága fölött nincs hatalma. (Beauvoir 1969, 384)

A tudatos félreértelmezés arra szolgál, hogy tovább lehessen görgetni a mondanivalót a „genderarcú jövő”, azaz a jelenünk felé és Beauvoir ürügyén a napi aktualitások szintjére lehessen emelni a szöveget, azaz a fent említett és a parlement által nem régiben elfogadott un. pedofil törvényt lehessen emlegetni, illetve parlamentünk bölcsességét lehessen dicsérni ezért a törvényért. A Lakner szöveg további része ugyanis Beauvoir kapcsán, tudatos zavarossággal összemossa a pedofíliát, a nemek és a homoszexualitás (a nemi binaritástól bármilyen módon eltérő szexuálitás) kérdéseit - hủen a 2021 évi LXXIX. törvény szellemiségéhez, amely egy törvénybe foglalva tárgyalja a gyermekek védelmét a pedofil bűncselekményektől és a heteroszexualitástól bármilyen formában eltérő szexualitás létezésének megismerésétől.

A Simone de Beauvoir-ral kapcsolatos információk nem csupán a Második Nem címú visszavonhatatlanul örökérvényú írás tökéletes meg nem értéséről, sőt tudatos és tendenciózus félreértelmezéséről szólnak, hanem jórészt a Beauvoir személyes, magánéletével kapcsolatos információk is hamisak, illetve tudatosan torzítottak. Itt történik az összemosás a pedofiliával, amikor Lakner azt írja: „Kiskorú, „második nemü” sžeretöi miatt ma nagyot szorulna parlamentünk pedofil ellenes törvényétöl, de a férjébez, Sartre-hoz, is átirányitott lánykákon ez. ma már mit sem segit." Beauvoir élettörténetét ismerve a 
valóságnak csak egy halvány lenyomatát fedezhetjük fel ebben az állításban. Lakner moralizáló értékelése részben a tények nem ismerete, részben azok elferdítése okán csak strukturálatlan indulatait fejezi ki. A főszerkesztő itt nem Beauvoir számos és gyakran párhuzamos párkapcsolatát állítja pellengérre és szögezzük le, nem házasságát, hiszen sosem házasodott meg, ergo Sartre nem volt a férje -, hiszen a párhuzamos, akár házasság melletti kapcsolatok gyakorlata napjaink politikusai körében sem ismeretlen (amiben persze semmi kivetni valót nem találnak a Lakner-féle felszólalók). Hanem a tanítványaival való - valóban zavarba ejtő - kapcsolataira utal, melyről utóbb több esetben is tanúságot tettek azok, akik szexuálisan kihasználtnak érezték magukat. Ugyanakkor, a pedofília szó emlegetése teljesen jogosulatlan csúsztatás, hiszen legfiatalabb tanítványa is 17 éves volt, amely életkor még a magyar büntető törvénykönyv (2012 évi C. tv.197 - 198. \$) szerint sem hozható összefüggésbe a „pedofil bűncselekményekkel” azaz a szexuális interakció Btk-ban megfogalmazott egyik formájával sem, hiszen a beleegyezési korhatár 14 év. ${ }^{3}$ Nem kérdéses az, hogy Beauvoir esetében a hatalmi viszonnyal való visszaélésrôl lehet és kell beszélni, ami miatt annak idején tanári állását fel is függesztették. És igen, valóban ezeknek a fiatal lányoknak, például Natalia Sorokine-nak, később Sartre-al is volt szexuális viszonyuk, Beauvoir-ral szerelmi háromszögben. Az egyik ismert könyv Bianca Lamblin (1996) tollából, Disgraceful Affair [Gyalázatos (szégyenletes) viszony] címen, hitelesen számol be ezekről az eseményekrôl és viszonyokról. Nem könnyú egy olyan nagyhatású gondolkodó, mint Beauvoir, hatalmi visszaélésével szembesülni! De nincs más választás, muszáj. Ennek fényében közölte a Simone de Beawvoir Studies a 15. évfolyamában (1998-1999), ami a Második Nem megjelenésének arany évfordulójára készült, Bianca Lamblin visszaemlékezéseit az ünnepi kötetben. Egyszerűen csak egymás mellé tették a filozófus hatásáról szóló méltató és a realitások másik oldalára reflektáló tanulmányokat és visszaemlékezéseket. Ezek mind a valóság részei voltak. Csak a szakmai oldal megjelenítése sértette volna azokat, akik áldozatai voltak az abúzusnak, míg csak a másik oldal, azaz kizárólag a magánéleti viszonyok megjelenítése ugyanolyan igazságtalan lett volna. Természetesen nem várhatunk hasonló fair viszonyulást Lakner Z. Leheltől.

3 A beleegyezés korhatára az az életkor, amikor egy személy jogilag kompetensnek minősül a szexuális cselekményekbe való beleegyezésre. A magyar jog szerint 12-14 év közötti személlyel, ha 18 éven felüli végez vagy végeztet szexuális cselekményt az a Btk. 198. (1) bek. szerint szexuális visszaélést követ el. Amennyiben 12 év alatti személlyel 14 év feletti személy végez vagy végeztet szexuális cselekményt, az a Btk. 197. \(2). bek. szerint szexuális erőszakot valósít meg. Franciaországban a beleegyezési életkor 1920-tól 13 év volt, tehát akkor is, amikor Beauvoir a tanítványaival szexuális kapcsolatra lépett. 


\section{És megint a „genderideológia”...}

A szám 5. oldalán található egyoldalas főszerkesztői vezércikk azonban nem ezzel, hanem a ,genderideológiával' kezdődik, amely szerzője szerint ,berúgta az. ajtót Magyarországon is. Követöi érzékenyités cimén hatolnak be az életvilagba, és kényszerítik rá nézeteiket a lakosságra. Aki ę̧ nem fogadja el, ellenáll, vagy egyszerüen csak nem érti, az a halál fia! Ez a mai valóság a 21. század Európájában.”

Ebben a kijelentésben, sok szó használatával súlyos gondok vannak. Kezdjük a „genderideológia” szóösszetétellel. Nem várom el Lakner Z. Leheltől, hogy ismerje a ,gender” szó jelentését és genealógiáját, sem azt, hogy tisztában legyen a feminista elméletek és társadalomtudomány vitáival, amelyek igen kritikusak a fogalom tekintetében, sőt, vannak, akik azt is felvetik, hogy a feminizmusnak nincs szüksége a gender (társadalmi nem) fogalmára. ${ }^{4}$ Ugyanakkor világosan látni kell, hogy a társadalom- és humán tudományok a „nem” fogalmát biológiai, anatómiai változóként használják a férfi és női különbségek jelölésére, míg a „gender” (társadalmi nem) fogalom pedig a két csoport közötti szocializált és hatalmi különbségek megragadására szolgál. A konstrukcionista álláspont azonban megkérdőjelezi ezt a kettősséget, mert úgy gondolja, hogy nem csak a „társadalmi nem” társadalmilag konstruált, de a „biológiai nem” koncepciója is, mely a 18. és 19. századi reproduktív élettani tudomány melléktermékeként született meg. A „biológiai nem” fogalma, a nemi különbségeket a férfi és a nő anatómiájában véli felfedezni (Schiebinger 1989, Laqueur 1990), ezért a „nem” „objektív” biológiai tényként kerül meghatározásra, anélkül, hogy belátná saját társadalmi meghatározottságát, azaz azt, hogy a biológiai magyarázat maga is társadalmi termék, saját(os) társadalmi történettel.

A gender szóval kapcsolatos képzeteket és társadalmi fantáziákat jól szemlélteti a lapszámban szereplő „A globális transzgender-ideológia és annak gyakorlati következményei" (Antalóczy 2021, 7 - 23) címú tanulmány Antalóczy Péter tollából, amely kivételes hatalommal ruházza fel a gender fogalmát. Ez szerinte, gyerekek tömegeit képes megrontani és a „nemváltoztatás mételyébe" csábítani. Szerencsére ennek a fogalomnak nincs ekkora hatalma. Egy kicsit mélyebb elemzés azonban megmutathatja, hogy a neoliberális kapitalizmus identitáspolitikái hogyan ürítették ki az egyéni választás szabadságának fogalmát és szűkítették manifesztációs tereit a nemi kérdésekre, elterelve a figyelmet az egyenlőség- és emancipációspolitikák teljes hiányáról. Az Antalóczy cikkben ${ }^{5}$ méltatott konzervatív republikanizmus jól

${ }^{4}$ Lásd például Jamima Repo The Biopolitics of Gender címú könyvét.

${ }^{5}$ Sajnos az idézett cikk több tekintetben sem felel meg a tudományos publikáció szabályainak. Egyrészt több helyen a szó szerint idézett (idézőjelbe foglalt) szövegek után hiányzik a pontos forrás megjelölés, lásd a 18. oldalon az Egészség és szexuális/reprodukciós jogok c. alfejezet 
ráérzett arra, hogy hogyan lehet a neoliberális gazdaságpolitika hatására kirobbanóan növekvő társadalmi egyenlőtlenségek felett érzett diffúz elégedetlenséget becsatornázni a bevándorlók, a női jogok és a szexuális kisebbségek elleni gyúlöletkeltő diszkurzusba, amely aztán ebben a mederben átirányítható a rendszer alapjait megkérdőjelező felháborodásból a rendszert fenntartó tradicionalista fundamentalizmusba. Ha jól belegondolunk, ugyanezt a jelenséget tapasztalhatjuk hazánkban is.

A „genderideológia” szóösszetétel másik tagja vonatkozásában fontos megmutatni az "ideológia" szó használatának azon sajátosságát, melyet többek között Clifford Geertz (1994) írt le. Geertz megmutatta, hogyan használják fegyverként az "ideológia" szót azok, akik meg akarnak bélyegezni egy irányzatot, vagy nézetrendszert és a leértékelés jegyében, a tudománytalanság értelmében alkalmazzák a leszólni vagy megsemmisíteni kívánt diszciplínához tapasztva a fogalmat. Így és ezért lett a társadalmi nemek tudományából genderideológia. ${ }^{6}$ Persze, minderrôl olyan nézőpontból ír Lakner Z. Lehel, teljesen reflektálatlanul, amely tényleg ideológia, a NER ideológiájának nézőpontjából. Bár nem hiszem, hogy nagyon átgondoltan alkalmazná a genderideológia kifejezést a szerző, inkább csak a magyar politikai és közbeszédbe tudatosan „szitokszóként” bevezetett tartalommal, minden gondolkodás nélkül.

\section{Szavak, szavak..., de mit is jelentenek?}

Aztán nézzük az “életvilág” kifejezést. A főszerkesztő szerint a genderideológia „Követöi érzékeenyités cimén hatolnak be az életvilágba, és kényszeritite rá nézeteiket a lakosságra." Bizonyára hallotta valahol Lakner Z. Lehel ezt a szót, de fogalma sincs róla, hogy mit jelent. Habermast meg biztosan nem olvasta, aki ezt a

első bekezdésében, ahol egyáltalán nincs forrásmegjelölés, vagy például a 19. oldalon a 26. számú lábjegyzettel megjelölt idézet, amely amellett, hogy magyartalansága miatt csaknem teljesen érthetetlen, nem tartalmaz pontos forráshivatkozást. Ez utóbbi hivatkozás megismerése és ellenőrizhetősége annál is inkább érdekes lenne, mert olyan szöveget, amely a „termékenység csökkentését” tűzte volna ki célul a nemi szerepek megváltoztatásával, vagy bármilyen más módon (Antalóczy 2021, 19), sem a UN Women (az Egyesült Nemzetek szervezete, amely a nemek közötti egyenlőségért és a nők szerepvállalásáért felelős https://www.unwomen.org/en), sem a DAW (UN Division for the Advancement of Women http://www.un.org/womenwatch/daw) nem publikált. Márpedig Antalóczy írása szó szerint, tehát idézőjelben idéz egy szöveget, amely erről szól. Szeretném felhívni a szerzők és szerkesztők figyelmét, hogy egy szociális szakembereknek szóló, tudományos igényú folyóiratban a hivatkozás szabályait maradéktalanul be kell tartani. Különösen akkor, ha ezt a folyóiratot kormányunk egyik igen fontos minisztériuma is támogatja.

${ }^{6}$ Ez volt az ELTE Társadalmi Nemek Tanulmánya MA programjának betiltása során is az egyik fontos érvelési stratégia (Barát 2019). 
fogalmat (Alfred Schütz nyomán) megteremtette és elemzéseiben következetesen alkalmazta is (1987). „Életvilág” alatt Habermas a társadalmi élet informális, piac és állam nélküli területeit érti: a család és háztartás, kultúra, szervezett pártokon kívüli politikai élet, civil társadalom, tömegtájékoztatás tereit. A társadalmiság ezen szférái a közös jelentések és megértések, valamint a más emberekkel való mindennapi találkozások számára a társadalmi horizontok egész tárházát nyújtják. Ez a horizont az a háttér, amely „előtt” a kommunikatív cselekvés zajlik. Az életvilágnak több funkciója van. Kontextust biztosít a cselekvésnek, mivel egy sor közös előfeltevésből és háttér tudásból áll, valamint egy sor közös indítékból, amelyre alapozva a cselekvők konszenzust érhetnek el. Az életvilág a társadalom szimbolikus és kulturális újratermelésének közege, itt zajlik a társadalom fennmaradása szempontjából fontos kultúra reprodukciója, az integráció helyreállítása és a szocializáció. Ezzel szemben áll a „rendszer”: a politikai-közhatalmi és a piaci erők instrumentális racionalitása, amely a későkapitalizmusban „gyarmatosítja” az életvilágot, azaz a hatalom és a pénz által vezérelt rendszerfolyamatok benyomulnak az életvilágba, és a társadalom fennmaradása szempontjából fontos reprodukciós mechanizmusokat próbálják átállítani saját múködési elvüknek megfelelően (Habermas 1987, 522-523. hivatkozza Némedi 2008, 614). Például a gazdasági alrendszer a magánszféra intézményein át behatol az életvilágba és eldologiasítja annak kommunikatív viszonyait (monetarizálás és bürokratizálás). Rendszer és életvilág dualizmusából, a kétféle rendszerképző médium (pénz és hatalom) kettősségéből következett az a feltevés, hogy a modernitásban a vezérlést éppúgy átveheti a politikai uralmi gépezet, mint a pénzre épülő piaci mechanizmus (Némedi 2008).

Tehát a habermasi fogalom szerint, az un. genderideológia követői, az érdekvédő civil szervezetek, ugyanúgy az életvilághoz tartoznak, mint a Lakner által áldozatként láttatott lakosság. Ráadásul, ezek az un. követők kisebbségi jogokat képviselve jóval gyengébb - tehát elvileg védendő pozícióban vannak, mint a többség, és nyilvánvalóan nincsenek eszközeik semmiféle kényszerítésre. Látható, hogy Lakner Z. Lehel egy olyan fogalmat használ, amelynek jelentését nem ismeri, ugyanakkor azt a látszatot kelti a témában tájékozatlan olvasóban, hogy valamiféle szakértő, aki tudatosan és értve alkalmazza azt.

A helyzet szarkazmusát csak növeli az a tény, hogy Habermas az életvilág fogalmát a kommunikatív cselekvés elmélete részeként dolgozta ki, amelynek lényege a kényszer nélküli „ideális beszédhelyzet”, vagy fair diszkurzus, amely távol áll attól a nyelvezettől, amelyet Lakner használ, és távol áll azoktól a jelenleg érvényes kommunikációs viszonyoktól, amelyet a regnáló politikai hatalom megteremtett, s melynek „bátran odamondogató” 
lelkes képviselője a szöveg szerzője. A másik oldalnak ugyanis nincs beszédjoga, nincs beszéd-tere: rendkívül korlátozott a nyilvánossága. A másik oldalon felvetett témák és megközelítések illegitimek, személyes támadásnak és inzultusnak teszi ki magát, aki ellent mer mondani az engedélyezett beszédnek. Akkor most ki is az, aki „halál fia”? Nyilván nem Lakner, a szöveg szerzője, hiszen ő a regnáló hatalom ritmusát dobolja! Ám mindazok sokat kockáztatnak, akik merészelnek nem egyetérteni a hivatalos kánonnal és azok „hitvallásával”, akik szükségét érzik annak, hogy e kánon mellett kinyilatkoztatást tegyenek.

Aztán itt van az érzékeenyités szó meghurcolása. Az érzékenyítés mások identitásának megértését és elfogadását célozza a társadalmi kohézió és tolerancia érdekben. ${ }^{7}$ Ám a Lakner szövegben - hủen tükrözve a kormányzati retorikát - Trójai Falóként kerül értelmezésre, ami valójában „a homoszexualitás népszerüsitése" lenne, ahogyan ezt a 2021 évi LXXIX. törvény nyomán módosított gyermekvédelmi törvény ${ }^{8}$ is megfogalmazza. Az önkényes és tendenciózus tartalmi átalakításon átesett érzééenyités ma már szabálysértésként büntetendő, ${ }^{9}$ ami lehetővé teszi annak megakadályozását, hogy civil érdekvédő szervezetek képviselői részt vegyenek iskolai érzékenyítő programokban meghívott előadóként. A köznevelésről szóló 2011. évi CXC. törvény új (a 2021. LXXIX. törvény által módosított) kiegészítése szerinti, a „jogszabályban kijelölt szerv által nyilvántartásba vett külsö elöadô" ugyanis egészen biztos, hogy nem érzékenyítést fog végezni az iskolákban, hiszen csak akkor fogják nyilvántartásba venni, ha a kormányzati kirekesztô és gyúlöletkeltő ideológiát képviseli. Tehát azok a szervezetek, amelyek például a szexuális kisebbségeket képviselik, szóba sem jöhetnek - erre egyébként egyértelmúen utal a Kormány 1438/2021. (VII. 6.) Korm. határozata a Magyarországot ért durva és antidemokratikus politikai támadásokról címú dokumentum is, amely világosan kimondja, hogy: „Nem engedhetjük, hogy a szülök helyett civil szervezetek

7 Az érzékenyítés során egy személy, csoport, populáció figyelmét hívják fel egy fontos (társadalmi) kérdésre. Célja, hogy a célcsoport figyelmét felkeltse, érzékenységét fokozza egy téma iránt. Az érzékenyítés az egyszerű tájékoztatásnál sokkal többet jelent. Az információ célja egy üzenet közvetítése. Az érzékenyítés során a résztvevőben nem tudatos folyamatok zajlanak, ez feltételezi az üzenet beépülését, az attitűd és a viselkedés megváltozását. Az érzékenyítés az egyén vagy a társadalom számára megadja a lehetőséget, hogy döntsön, és felelősséget vállaljon életének irányításában (Berti et al. 1998).

${ }^{8}$ A gyermekek védelméről és a gyámügyi igazgatásról szóló 1997. évi XXXI. törvény 6/A. 』 ${ }^{9}$ A 2021. évi LXXIX. törvény kiegészítette a 2012. évi II. törvényt a szabálysértésekről: a 248. \(3) bekezdése a következő d) ponttal egészül ki: (Aki) „d) a köznevelési intézményben tartható foglalkozások tartására, vagy azok törvényessége ellenőrzésére vonatkozó rendelkezéseket megszegi, (szabálysértést követ el.)”. Magyar Köz̨löny 2021. évi 118. szám 4948. oldal. 
gyámsága alá belyez:ék a gyermekeinket." A bevett egyházak gyámsága ellen azonban nincs kifogása a törvényalkotónak.

És itt van a „termész̨et rendje”, ami a szövegben később kerül elő. Milyen ismerős hivatkozás! A természet rendje nemrég még azt követelte, hogy a lányokat 14 éves korban férjhez adják, akik aztán életük során tucatnyi gyermeknek adtak életet, meg azt, hogy alárendelődjenek a férfiaknak, hogy elviseljék akár a bántalmazást, hogy ne lehessen tulajdonuk. Vagy más viszonyok között a „természet rendje” a nőket hidzsábba, niqabba, burkába, chadorba burkolja ma is. A természet rendje magától értetődő, nem szorul igazolásra! Isten ments megkérdőjelezni, vagy gondolkodni rajta! Ezen a „,renden” komoly réseket ütött a feminizmus, nehéz lesz visszaszorítani a szellemet a palackba, ha már Lakner is azt mondja: „Növédelemre termésæetesen nagy a szülkség..." és a „szerephátrányok mérséklésére”. Lakner taktikája alázatosan igazodik a kormányzat által megengedett „,nővédelem” és „,szerep” diszkurzus fogalomköreihez, amire „szükeség van”. Amiről azonban élesen leválasztja a „gellert, söt rakétatöltetet' kapott „,szexuális sqabadosságot”, amely ma már átcsapott „férfi ellenességbe, sok esetben egyenesen a homoszexuális kultúrák eröszakos követelésáradatába".

A „nővédelem” tehát legitim. De miféle nőképet konstituál ez a „nővédelem” és kitől is kell megvédeni a nőket? És az állítólagos szabadosság láttán miért nem férfivédelemre van szükség? És miféle szerephátrányokról beszélünk? Talán arról, hogy a nők hatalomhoz való hozzáférése a mai napig korlátozott? Hogy a regnáló hatalom ismét a családi tűzhely őrzőiként szeretné látni őket és nem az egyetemeken, a vállalatok és az ország vezetésében? Úgy kívánják ismét, hogy ne legyen más feladatuk csak a „nyilvánosságban megüdvözülő és a hazáért dolgozó” férfiak biztonságos hátterének megteremtése, s a népesség bővített reprodukciója (a munkaerő reprodukciója és produkciója)? Amely férfiak aztán rendszeresen ruganyosabb, friss „húsokkal” váltják majd le őket? Nézzük csak meg regnáló politikusaink új feleségeinek életkorát, a korábbi asszonyokhoz és az egyre deresedő férfiakhoz képest! Persze, ez mind része a „természet rendjének”. Ahogyan a természet rendje teszi azt is, hogy a maszkulin dominancia, a férfiuralom (Bourdieu 2000) viszonyainak elemzése „a férfi ellenséggé minösitésévé” változik, a hegemón maszkulinitás (Connell 1995) és a heteronormativitás összetevőinek vizsgálata és bírálata ${ }^{10}$ pedig a „,homoszexuális kultúrák erösqakos követelés-áradata” lesz a Lakner logika mentén.

A „szerephátrányok” kifejezés talán azért lehet legitim a szerző számára, mert megfelelő politikai helyről kijelentették, hogy „társadalmi nemek nincsenek,

${ }^{10}$ https://eige.europa.eu/thesaurus/terms/1237 
társadalmi szerepek azonban vannak." "11 Azt nem várhatjuk a főszerkesztôtől, hogy tudja: a „szerephátrány” kifejezést a nemek összefüggésében a gender kutatás vezette be a köznyelvbe, ahogyan annak ismeretét sem, hogy a mértékadó szakirodalom a „,szerep” fogalmat erősen kritizálja, mint a nemek közötti társadalmi különbségek funkcionális magyarázatának statikus eszközét, amely eltakarja a tényleges konstruáló erőt, a hatalmi különbségeket.

Lakner Z. Lehel fôszerkesztő természetesen lefutja a kormányzat által kijelölt kötelező köröket és belerúg a kiszemelt ellenségekbe: a harminc éve „döglött oroszlánba”, nevesítve „a tudományosnak maszkirozott szocializmust”; az Európai Unióba, szembe állítva a „zöld-lobby” és a környezetvédelem törekvéseit a fehér-europid ember kipusztulásának rémképével: „Tekintetül. sötétrölldbe hanyatlik, és „a sok ember sokat eszik, tehát rombolja a körmyezetet elv" biveiként ájulatig tapsolják az önmagát kiirtani kész gyermektelenül beteg Európát."

A főszerkesztői opusz mélypontja azonban a „genderideológia” vélt szabadságfogalmának sajátos értelmezése, olyan módon, hogy az belegázol embercsoportok méltóságába, kigúnyolva a szeretet törvényét, pellengérre állítva a „család az család” jelmondatot, amely kiállás azon kisebbséget alkotó honfitársaink mellett, akiket a regnáló hatalom démonizál. Ez igazán bátor tett!

\section{Üzenet szociális szakembereknek}

Végezetül még egyszer vissza kell utalnom a Lakner Z. Lehel által használt „életvilág” kifejezésre, méghozzá a szövegnek a Szociálpolitikai Tükörben történő megjelenése kapcsán. E folyóirat a Szociális Igazgatók és Szakemberek Magyarországi Egyesületének kiadásában jelenik meg, egyértelmủen a szociális területen dolgozó szakemberek érdeklődésére igényt tartva. Itt jön képbe az „életvilág” kifejezés még egyszer. A habermasi életvilág - rendszer elmélet szociális munkára történő alkalmazása szerint a szociális munka, részben a szociális munkás - kliens dialogikus kapcsolaton, részben pedig azon keresztül, hogy a szociális munkás saját személyiségével (személyességével) dolgozik, az életvilágra jellemzọ kommunikativ cselekvés részét képezi. Ugyanakkor a szociális munkára a rendszer és életvilág elemek egyidejü jelenléte és jóesetben egyensúlya jellemző (Cooper 2010, 169-184). A szociális munkás egyszerre van az életvilág és a rendszer (a szociális intézmények és

${ }^{11}$ Balog Zoltán, emberi erőforrások miniszterének kijelentése 2017. március 8-án a Corvinus Egyetemen tartott nőnapi konferencián. Forrás: https://index.hu/belfold/2017/03/09/megsem indit csaladtudomanyi mesterkepzest a kormany a corvinuson/ és https://www.origo.hu/itthon/20170308-balog-tarsadalminemek-nincsenek-tarsadalmi-szerepek-azonban-vannak.html 
szolgáltatások a rendszer részét képezik, hiszen állami - hatalmi politikákat valósítanak meg, még akkor is amikor nem állami intézményekben valósulnak meg) között, de azokon kívül müködik és egyaránt szüksége van mindkettőre (Rode 2017). Állami felhatalmazás nélkül a szociális munka ugyanis a jótékonyságra vagy önsegélyre szorítkozhatna. A szociális munkások számára azt a megbízást, hogy a kijelölt „célcsoportokkal” dolgozzanak, és beléphessenek klienseik életvilágába, az állam biztosítja. Egyúttal a szociális munka, mint speciális szakma, jogi és anyagi létét is. Ezért, és a szociálpolitikához való kötődése miatt, a szociális munka szorosan kapcsolódik az államhoz és annak bürokráciájához. A szociális munkának tehát két mandátumot kell megszereznie: a rendszer mandátumát, valamint a közösség és a kliens megbízását (segítségnyújtási mandátum), miközben, mint hivatás létrehozza saját erkölcsi-gyakorlati mandátumát is, amely a szociális munka etikáját generálja (Rode 2017). A szociális munka tehát a szociális szakemberen és a kliensen keresztül is az életvilághoz tartozik, s ekképpen részt vesz a "a társadalmi integrációhoz szüleséges közös értékek és érdekek létrehozását elösegitó társadalmi párbeszéd kialakitásában" - ahogyan Habermas mondja -, amely érdekvédő funkcióján keresztül képes a hatalom nélküliek hangjának felerősítésére (Habermas 1987, 149-150).

Tehát, ha már az „életvilág” fogalmát használja Lakner Z. Lehel egy olyan szociálpolitikai folyóiratban, amelyet szociális szakembereknek írnak, akkor a szociális munka alapfeladatával és funkciójával tisztában kellene lennie: társadalmi integráció, közös érdekek és értékek létrehozását elősegítő párbeszéd! Az integráció nem lehet kirekesztés és diszkrimináció, ${ }^{12}$ nem lehet egyes társadalmi csoportok leértékelése és megbélyegzése. A párbeszéd pedig nem jelenthet indulatos gondolatrohamokat. Egy ilyen folyóirat szerzője (különösen, ha annak föszerkesztője) feltehetően tisztában van a szociális munkások etikai kódexével:

tevékenységét etikai tudatossággal végzi, tiszteletben tartja minden ember méltóságát, értékét, jogait, védelmezi testi-, lelki-, értelmi-, erkölcsi- jól-létét, tartózkodik minden olyan megnyilvánulástól, amely diszkriminációt idézhet elő, elismeri és tiszteletben tartja a társadalom sokszínúségét, figyelembe veszi az egyéni, családi, csoportos és közösségi különbségeket, stb. ${ }^{13}$

Ez vonatkozik a szexuális mássággal élőkre is és azokra is, akik úgy gondolják, hogy a Modernitás nem „az emberi személyiség lényegét képező identitástartalmak szétverését, azaz a nemzeti, a vallási - különösen a

${ }^{12}$ Egyben ezzel utalok a számban Antalóczy Péter tollából megjelent tanulmányra is, amely azt bizonygatja, hogy a diszkrimináció valójában nem az (Antalóczy 2021, 23).

${ }^{13}$ A Szociális Munka Etikai Kódexe. Forrás: http://3sz.hu/sites/default/files/Etikai.pdf 
keresztény - és végül a nemi identitás megrendítését, lebontását" (Lakner 2021, 46) végezte el, ahogyan Lakner e lapszámban megjelent tanulmányában írja, hanem az identitástartalmak átalakultak; nem megrendültek, hanem a történelemben folyamatosan változnak, és legalább olyan fontos az egyéni szinten meghatározott identitás, mint a közösségi. A közösség nem gyakorolhat terrort az egyéni identitás-meghatározás fölött. E sorok írója tisztában van a Modernitás „sötét oldalával” (Alexander 2013), amely sok bizonytalanságot és feszültséget „öntött a nyakunkba” a közösséghez kötődés szálainak meggyengülése és az egyéni szabadság határainak kitolódása okán, ${ }^{14}$ és sokak szerint ennek a feszültségnek a csökkentését szolgálja a "Más” megteremtése, amelybe bele lehet vetíteni a szorongást (Alexander 2013). A „Más” bizonyos csoportok azonosítására utal, amelyek fenyegetést jelentenek a nemzetre nézve, oly módon, hogy a társadalmi szerződésből (azaz az állam garanciáiból és védelméből) való kizárásuk legitimált. A „Más” bủnbak lesz az „identitások megrendítése” és a változások végtelen sora miatt, az egyéni felelősség néha elviselhetetlen terhének érzete miatt, a fel nem oldható ellentmondások számossága felett érzett szorongásért. Ugyanakkor ez a Modernitás teremtette meg azt a világot, amelyben Lakner Z. Lehel főszerkesztő lehet és vezércikket írhat a szociális munkásoknak és a szociálpolitikusoknak, ugyanis ez a Modernitás hozta létre ezeket a professziókat, csak úgy, mint a mindenki számára elérhető újságot, és a vélemény szabadságát is. A szorongás feloldásának, s az identitás megteremtésének pedig nem csak ellenségek kijelölésén és kirekesztésen alapuló módjai ismertek. Az is tudható, hogy a folyamatos ellenségképzés, a barát-ellenség reláció megteremtése és újratermelése - Carl Schmitt (2002 [1928]) politikai fogalma szerint - identitás-képző, és a „demokrácia” schmitti fogalma homogén démoszt követel, amely nem fér össze a pluralizmussal. Nem tudom, hogy Lakner Z. Lehel érti-e, hogy ezt a „mi-ők” (mi a jók - ők a rosszak, az ellenségek) alapon felépülő politikai identitásteremtést szolgálja írásaival. A szociális munka nem szolgálhatja ezt a politikai logikát, sőt tiltakoznia kell, és ellen kell állnia ennek a logikának.

A szociális munka, mint az életvilág része erőteljesen ki van téve a rendszer kolonizáló hatásának. A társadalmi rendszerek modern differenciálódása autonóm alrendszereket eredményezett, amelyek a demokratikus kontrolltól viszonylag függetlenül múködnek. Ezek az autonóm alrendszerek „elszakadnak az életvilág asszimiláló batalmától és normativ kontextusátóp' (Habermas 1987, 173) és instrumentális értékeken és az üzleti világ prioritásain vagy/és az állam bürokratizáló, politikai ideológiák mentén preferenciát gyakorló tendenciáin keresztül működnek. Ez rámutat arra, hogy

14 Az egyéni tudat válsága (Alexander 2013; Giddens 1990) és szervezeti válság (Foucault 2008, Agamben 2005) következett a modernizáció „sötét” oldalából. 
a szociális és jóléti politikák alrendszerében a stratégiai és instrumentális racionalitáson keresztül hogyan itatja át és dominálja a szociális munka gyakorlat szakmai kultúráját a piaci szemlélet és a menedzserizmus (Cooper 2010) egyfelől, a bürokratikus „akta professzionalizmus” és technicizálódás (Bryson 2019) pedig másfelől. Mind a két irányt fokozottan meg lehet figyelni a magyar szociális ellátórendszer múködésében. Ugyanakkor a rendszerben dolgozó szakemberek korlátozottak abban, hogy észlelni és reflektálni tudják a rendszerértékeinek és múködési elveinek térfoglalását. Ennek okát Habermas abban látja, hogy a rendszer a kulturális tudat „széttöredezettsége” miatt dominál. Az életvilágban lévő mindennapi tudás ugyanis szétszórt, de legalábbis soha nem éri el azt az artikulációs szintet, amelynél a tudás önmagában érvényesnek fogadható el a kulturális modernitás standardjai szerint. Lényegében ezzel jönnek létre az életvilág gyarmatosításának feltételei, ahol a helyi kultúra szétszórt, perspektívái gyakran nem képesek felfogni a rendsæer imperatívuszainak behatolását (Habermas 1987, 355). Ha meg is történik ennek felismerése a szakmaiság és az etikai elköteleződés mentén, ez gyakran úgy tűnik fel, mint a szociális munka immanens konfliktusa, melyben az állam által preferált tekintély és ideológia, valamint a kevés hatalommal bírók iránt érzett felelősség ütközik. Ennek a konfliktusnak a feloldása kizárólag egy nyílt, és a kommunikatív etika szabályait követô, az ágazati politikákat képviselő és a politikákat végrehajtó szakemberek közötti párbeszéd keretében lehetséges, amely a szociális munka életvilág és rendszer elemeinek egyensúlyához vezethet. E sorok írója úgy látja, hogy a regnáló hatalom fó tematikáinak, a másságot kirekesztô diszkurzusainak kritikátlan átvételével, sőt felfokozott kihangosításával Lakner Z. Lehel a politikai rendszer képviselőjeként a szociális szakma állam általi kolonizációjának brókere.

Egy ilyen stílusú és kidolgozottságú vezércikket akár az 50-es években is írhattak volna. Nem a gondolkodás a lényeg, csak az ellenszenv kifejezése, az ellenségek kijelölése és annak demonstrálása, hogy a szerző beállt a sorba, a regnáló hatalom és ideológiája mellett „bátran” kiállók siralmas sorába. Az új és bátor megszólalás ma a „vitathatatlan tekintéllyel” való azonosulás kifejezése, az ő gondolatainak átfordítása minden lehetséges területre és diszciplínára, azok interpretálása, sôt továbbfejlesztése. Ma ez az új „Népszabadság félóra”! Ha ez még mond valakinek valamit...

\section{Felhasznált irodalom}

Agamben, Giorgio. 2005. Homo Sacer: Sovereign Power and Bare Life Stanford. California: Stanford University Press. 
Alexander, Jeffrey C. 2013. The Dark Side of Modernity. Cambridge, UK; Massachusetts, US: Polity Press.

Antalóczy Péter. 2021. „A globális transzgender-ideológia és annak gyakorlati következményei." Szociálpolitikai Tükör 3 (1-2): 7 - 23.

Barát, Erzsébet. 2019. „Revoking the MA in Gender Studies in Hungary and Right-Wing Populist Rhetoric." L'Homme 30 (2): 135-144.

Berti, Cathi-Debacker, Maryvonne-Chervin, Philippe-Comte, Bénédicte \& Robert, Aline 1998. Awareness activities about bandicap. Technical Coordination of social and community Rehabilitation. Handicap International, Bangladesh.

Bourdieu, Piere. 2000. Férfiuralom. Budapest: Napvilág Kiadó.

Bryson, Stephanie A. 2019. „Can the Lifeworld Save Us From Neoliberal Governmentality? Social Work, Critical Theory, and Habermas.” Journal of Sociology \& Social Welfare 46 (3): 63-90.

Connell, R.W. 1995. Masculinities. Berkley, California: University of California Press.

Cooper, Barry. 2010. Educating social workers for lifeworld and system. In: Murphy, Mark and Fleming, Ted (szerk.) Habermas, Critical Theory and Education. International Studies in the Pbilosophy of Education. London: Routledge.

de Beauvoir, Simon. 1969. A második nem. Budapest: Gondolat Kiadó.

Foucault, Michel. 2008. The Birth of Biopolitics Lectures at the Collège de France, 1978-79. Basingstoke, New York: Palgrave MacMillan.

Geertz, Clifford. 1994.[1973] Az ideológia mint kulturális rendszer. In Clifford Geertz: Az értelmezés hatalma: Antropológiai írások. Budapest: Századvég Kiadó, 22-62.

Giddens, Antony. 1990. The Consequences of Modernity. Cambridge, UK: Polity Press.

Habermas, Jürgen 1987. The Theory of Communicative Action, Volume 2. Lifeworld and System: A Critique of Functionalist Reason. London: Beacon Press.

Lakner Zoltán Lehel. 2021. „Hús.” Szociálpolitikai Tükör 3 (1-2): 5.

Lakner Zoltán Lehel. 2021. „A nő és az „antinő” - avagy a teremtett világ fölszámolása." Szociálpolitikai Tükör 3 (1-2): 24-46. 
Lamblin, Bianca. 1996. A disgraceful affair: Simone de Beawvoir, Jean-Paul Sartre, and Bianca Lamblin. Boston, Mass: Northeastern University Press.

Laqueur, Thomas. 1990. Making Sex: Body and Gender from the Greeks to Frend. Cambridge, Mass.: Harvard University Press.

Némedi, Dénes. 2008. Jog és tárgyalásos politika. In Modern szociológiai paradigmák. Némedi Dénes (szerk.) Budapest: Napvilág Kiadó.

Repo, Jamima. 2015. The Biopolitics of Gender. Oxford University Press.

Rode, Nino. 2017. „Defining social work is a never-ending story.” European Journal of Social Work 20 (1): 64-75.

Schiebinger, Londa. 1989. Mind has no Sex. Women in the Origins of Modern Science. Cambride, Mass.: Harvard University Press.

Schmitt, Carl. 2002. [1928] A politikai fogalma. Budapest: Attraktor / Pallas Stúdió. 